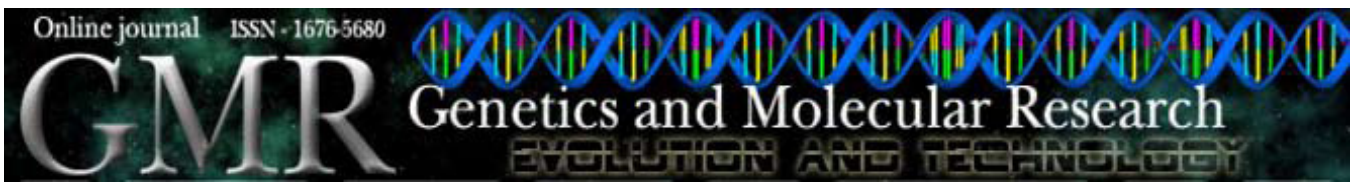

\title{
Internal phloem in an interspecific hybrid of cassava, an indicator of breeding value for drought resistance
}

D. Graciano-Ribeiro' ${ }^{1}$, D.Y.C. Hashimoto ${ }^{2}$, L.C. Nogueira ${ }^{2}$, D. Teodoro' ${ }^{2}$, S.F. Miranda ${ }^{2}$ and N.M.A. Nassar ${ }^{2}$

${ }^{1}$ Departamento de Botânica, Universidade de Brasília, Brasília, DF, Brasil

${ }^{2}$ Departamento de Genética e Morfologia, Universidade de Brasília, Brasília, DF, Brasil

Corresponding author: N.M.A. Nassar

E-mail: nagnassa@rudah.com.br

Genet. Mol. Res. 8 (3): 1139-1146 (2009)

Received April 22,2009

Accepted July 3, 2009

Published September 22, 2009

\begin{abstract}
We examined the stem anatomy of Manihot esculenta Crantz and its hybrid with $M$. oligantha Pax. Cross-sections were stained with safranin-alcian blue. Manihot esculenta and its hybrid were found to have the same vascular structure in bicollateral bundles with internal phloem, which has been associated with drought resistance in other plant groups. If this association is established for cassava, it would facilitate the selection of lines that are more adapted to arid regions. This is the first report of internal phloem in this genus.

Key words: Bicollateral bundles; Euphorbiaceae; Internal phloem; Breeding improvement; Manihot esculenta Crantz;

Manihot oligantha Pax
\end{abstract}




\section{INTRODUCTION}

Internal phloem in some higher plants is related to physiological processes involved in drought resistance (Esau, 1974). Bicollateral bundles, which are composed of both internal and external phloem (Flores-Vindas, 1999; Ye, 2002), have been observed in various plant families, such as Apocynaceae, Convolvulaceae, Cucurbitaceae, Solanaceae, Asteraceae (Mauseth, 1988; Fahn, 1990), and Lythraceae (Mundo and Duarte, 2007).

In the Euphorbiaceae, collateral vascular traces are found in Jatropha (Dehgan, 1982), in basal regions of the petiole. Popham (1947) reported on differentiation of cell groups of primary phloem outside the procambium in Jatropha cordata; however, he did not report internal phloem. Hayden and Hayden (1994) described internal phloem in Croton glandulosus var. septentrionalis, a species belonging to the same subfamily as Manihot.

Metcalfe and Chalk (1983) listed some genera of Euphorbiaceae that possess internal phloem, but Manihot was not included. There have been very few anatomical studies on this genus (Graciano-Ribeiro et al., 2008; Nassar et al., 2008b). We examined the anatomy of vascular bundles in Manihot because of its potential importance in the development of droughtresistant varieties.

\section{MATERIAL AND METHODS}

Stem samples of Manihot esculenta Crantz (cassava cultivar) and its hybrid with $M$. oligantha Pax were collected from plants maintained in the living collection of the University of Brasília Experimental Station (Brazil). The stem samples were fixed in 70\% formaldehydealcohol-acetic acid and stored in 70\% ethanol (Johansen, 1940).

The transverse cross-sections were enumerated sequentially in the apex-base direction, as follows: 1) cross-section near the apex; 2) cross-section at $2 \mathrm{~cm}$ from the apex; 3) crosssection at $5 \mathrm{~cm}$ from the apex; 4) cross-section of the middle portion of the second internode; 5) cross-section of the middle portion of the fifth internode (cf. Hayden and Hayden, 1994).

The free-hand sections were cleared in 50\% sodium hypochlorite solution (Kraus and Arduin, 1997), stained with 1\% safranin-alcian blue (Luque et al., 1996), dehydrated in an ethanol series and butyl acetate, and mounted in synthetic resin (Paiva et al., 2006). Photomicrographs were taken using a Zeiss Axioskop microscope, and the images were captured with the Motion Image Plus 2.0 software.

\section{RESULTS}

The epidermis is composed of common epidermal cells, stomata, and long unicellular tector trichomes. In the cortical region (Figure 1A), a three-stage differentiation was noted: a) initially, three to five layers of irregular-shaped and slender cell walls and laticifers, b) a segment of four to six layers of cells with slightly thickened walls, followed by one to three layers of irregular cells bordered by small intercellular spaces, and c) one last layer containing druses and crystals. Anticlinal and periclinal divisions could still be observed in these tissues.

Two regions could be seen in the tetraploid hybrid, with fewer layers and some druses (Figure 1D,E). Cross-sections of the cultivar differed at the advanced stages of differentiation by a greater number of layers and cell diameter and presence of starch-rich cells in the last 
layer (Figure 1F). The next region had 4-6 layers of small polygonal cells with slender walls, without intercellular spaces, but similar in content.

In relation to the hybrid, in Region 1, the vascular system consisted of external primary phloem, with the primary xylem spread out in five bundles and followed by internal primary phloem. Between the primary phloem and the primary xylem, differentiation of procambial cells was observed. The external primary phloem, which was in a cord distribution, showed approximately six layers of differentiating cells; in some places, sieve elements, companion cells, parenchyma cells, and laticifers were observed (Figure 1B). The external primary phloem was separated by small parenchyma cells.

The primary xylem had entered the phase of differentiation: the protoxylem was at an advanced stage, exhibiting smaller elements and thickened walls (the farthest ones were collapsed); the metaxylem exhibited larger elements, and the xylem was involved with parenchyma tissue consisting of small, thin-walled cells with no apparent content. There were elements of primary phloem (sieve elements, companion cells, and laticifers) along the primary xylem spread into the parenchyma tissue. Sieve plates in the sieve elements were observed of the internal primary phloem ((Figure 1C).

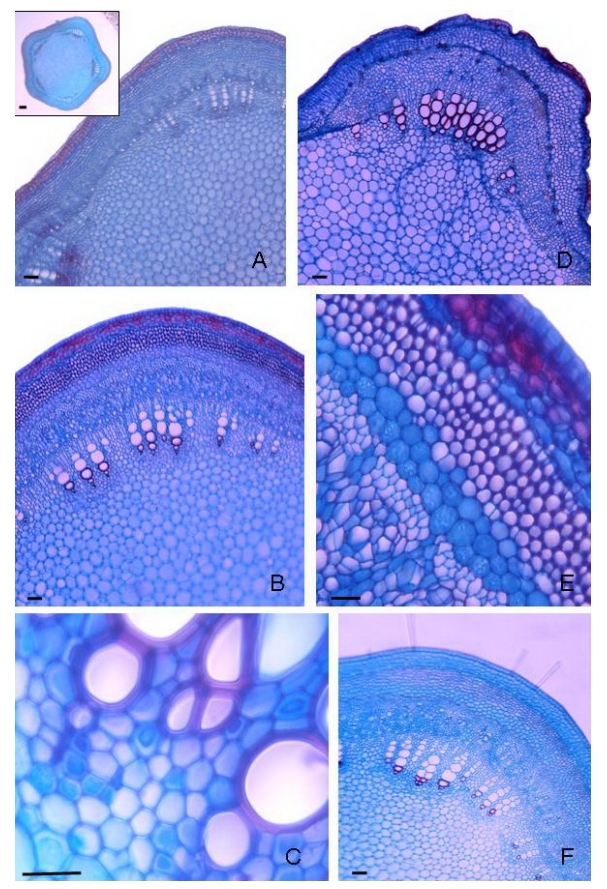

Figure 1. Transversal cross-sections of the Region 1. A-C. Diploid hybrid between Manihot esculenta Crantz x M. oligantha Pax. A. General view with primary structures; five vascular bundles are seen in the corners. Cortical region in detail, vascular cylinder and medulla. B. Cortex with three distinguishable parts; vascular tissue in formation, external phloem, protoxylem, metaxylem and internal phloem. C. Sieve plates in the sieve elements of the internal primary phloem. D,E. Tetraploid hybrid between Crantz x M. oligantha Pax. D. Beginning of the primary structure, only two distinct parts are noted; great amount of elements and thickened walls in the vascular tissue, divisions in medulla. E. Formation of collenchyma cells and starch sheath. F. M. esculenta cultivar shows more layers, bigger cell diameter and more cell differentiation. Bar $=100 \mu \mathrm{m}$. 
With regard to the tetraploid hybrid, the same pattern was observed. However, the primary xylem exhibited thicker-walled cells and the internal phloem was at an advanced stage showing more cells (Figure 1D,E). The cultivar differed from its diploid hybrid by the greater quantity of vascular tissue, cell diameter, and the presence of druses (except in vascular tissue) (Figure 1F).

The medulla showed polyhedral cells with 5-8 sides with no apparent cellular content (Figure 1B). The cultivar, on the other hand, showed no intercellular space, cell divisions or druses (Figure 1F).

Region 2 showed similar layers compared to Region 1 in the external cortex, but at an advanced stage of differentiation. No modifications were observed in these structures (Figure 2A).

In the primary phloem, cell divisions were noted, mostly periclinal and some anticlinal ones. Between the external primary phloem and primary xylem, some parenchyma cells were dividing, probably components of the fascicular cambium, characterizing secondary growth (Figure 2B). Secondary wall thickening was observed in primary xylem elements. Internal primary phloem was totally differentiated in the medullary region with polygonal-shaped cells. Internal primary phloem had no modifications.

The tetraploid hybrid showed different components of starch in the starch sheath and druses in the medulla, revealing xylem and phloem with greater cell diameter. In the cultivar, xylem and phloem tissues showed many cell divisions and initial development of the fascicular cambium (Figure 2C).

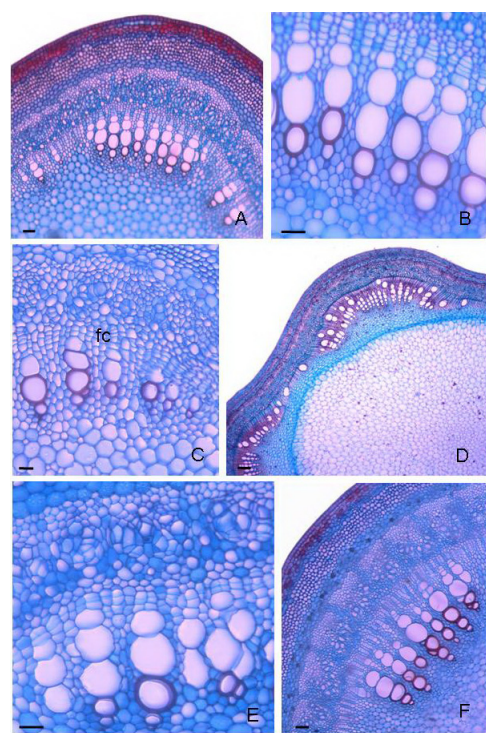

Figure 2. Transversal cross-sections of the Region 2 (A-C) and Region 3 (D-F). A,B. Diploid hybrid between Manihot esculenta Crantz x M. oligantha Pax. A. Cortical tissues under differentiation: parenchyma with anthocyanin, angular collenchyma, parenchyma and starch sheath; beginning of the secondary growth with vascular cambium. B. Fascicular cambium, primary xylem and internal primary phloem. C. M. esculenta cultivar. Secondary growth is slower, noted by lesser number of cells in the fascicular cambium (fc). D. Diploid hybrid between M. esculenta Crantz x M. oligantha Pax. Fascicular cambium in activity with formation of secondary xylem and phloem, beginning of the interfascicular cambium, medullary cell divisions. E. Tetraploid hybrid between Crantz x M. oligantha Pax. Development of external phloem and primary xylem, by the presence of protoxylem and metaxylem. F. M. esculenta cultivar. Great amount of druses and starch grains in the cortical and medullary regions. Bar $=100 \mu \mathrm{m}$. 
In Region 3, cells in the layers next to the vascular tissue showed secondary wall thickening, giving them a different appearance compared to the fibers (Figure 2D). The external primary phloem showed the collapse of some cell types, mostly sieve elements and companion cells. The formation of both secondary phloem and secondary xylem was observed in the fascicular cambium. Some regions, which were related to inter-fascicular cambium formation, showed dividing cells. In the medulla, parenchyma cells also began to divide to form polygonal cells wider and narrower than the previous ones. The tetraploid hybrid showed similar developmental events as in the diploid one (Figure 2E). In the cultivar, the fascicular cambium was complete (Figure 2F).

Region 4 showed cambium forming a complete cylinder and intense cell divisions. Laticifers of secondary origin were formed from these cells. There was intense dissolution of external primary phloem elements and addition of new peripheral parenchyma cells to the medulla. The cultivar had an increased number of druses and starch grains in all tissues, except in the vascular one (Figure 3A).

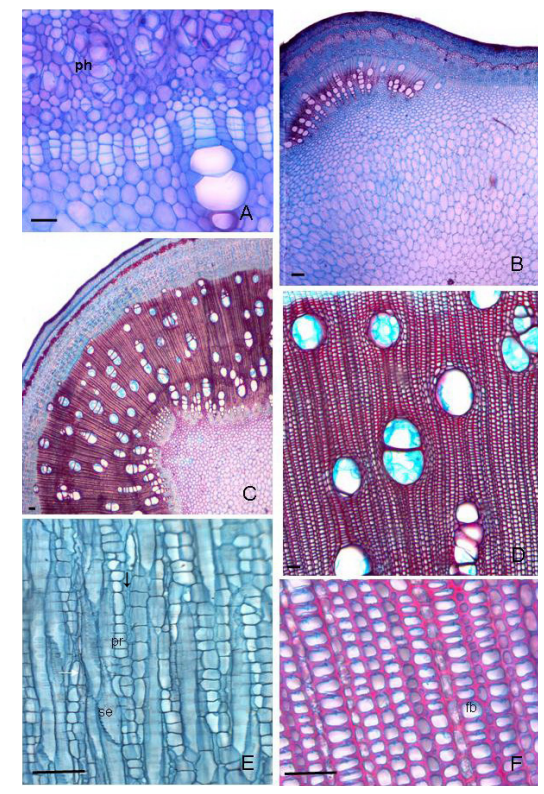

Figure 3. Transversal cross-sections of the Region 4 (A) and Region 5 (B-F). A. Manihot esculenta cultivar interfascicular cells and phloem (ph) in differentiation. B-F. Diploid hybrid between M. esculenta Crantz x $M$. oligantha Pax. B. Establishment of vascular cambium in intense divisions and new cells added in medulla. C. Accentuated secondary growth. D. Secondary xylem in detail. E. Longitudinal cross-section showing laticifers (black arrow), sieve elements and companion cells (white arrow), pr: radial parenchyma, se: sieve element. F. Secondary xylem with parenchyma cells and fibers (fb) with slender walls. Bar $=100 \mu \mathrm{m}$

In Region 5, secondary growth (Figure 3B and C) with phellogen and active vascular cambium was observed. The stem showed, from outside to inside, the following tissues: epidermis (sometimes interrupted by periderm), variable number of phellogenic layers, sporadic lenticels, cortical parenchyma with idioblasts (druses and prismatic crystals) and isolated laticifers, and angular collenchyma with up to five cell layers. One layer of parenchyma cells had crystals, druses and starch, forming a starch sheath. Pericyclic fibers were formed by an 
interrupted cylinder with thickened wall. Dissolutions of the conducting cells occurred in the external primary phloem, leaving laticifers and parenchyma.

In the secondary phloem, which had about 12 layers, sieve elements, companion cells and laticifers in rows of small clusters were observed, including other parenchyma cells (Figure $3 \mathrm{E}$ ). Phloem parenchyma rays were continuous with the secondary xylem. In the secondary xylem, there were vessel elements, xylem fibers, tracheids, radial parenchyma, and vasicentric axial or scanty paratracheal parenchyma.

The vessel elements were solitary or clustered, often showing tyloses, and radial parenchyma cells were rectangular and arranged in rows (Figure 3D). Xylem fibers showed few lignified walls, wide lumen, and rectangular shape (Figure 3F). In addition to these structures, the secondary xylem tissue showed some layers that appeared to be secondary growth rings. Protoxylem and metaxylem elements were evident; phloem elements were involved with parenchyma cells.

The medulla could be divided into two regions according to cellular shape, content, and number of layers. The first one, peripheral medulla, was near the primary xylem and had isodiametric cells; the second one, central medulla, had polygonal cells with 5-6 faces (Figure 3B). The cells were larger in this region.

In the tetraploid hybrids (Figure 4A-C), fibers had slender walls, phloem tissue had greater cell diameter and more laticifers, and xylem had more solitary vessel elements, greater diameter, and more starch deposition in fibers and radial parenchyma. The cultivar (Figure 4D-G) had fewer fiber layers and slender walls, greater number of laticifers, larger cells in the vascular tissue, more layers of xylem, prevailing solitary vessel elements with greater diameter and starch amount in all kinds of cells. In the medulla, cells were larger and narrower with thinner cell walls. These data confirm that size, quantity and thickening of vascular elements increased with higher ploidy level.

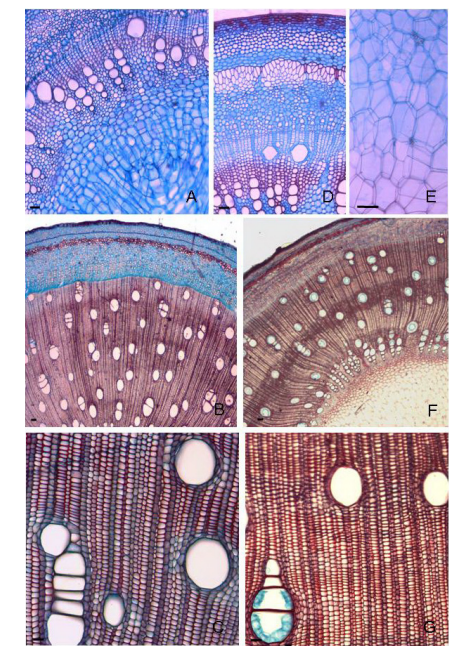

Figure 4. Transversal cross-sections of the Region 5 (A-C). Tetraploid hybrid between Crantz x Manihot oligantha Pax. A. Secondary growth in detail, formation of secondary xylem and phloem from the vascular cambium; medullar parenchyma in division to form narrower and elongated polygonal cells. B. Accentuated secondary growth, great amount of vascular tissue, as bigger diameter of conductive elements and lesser quantity of tyloses than the diploid type. C. Secondary xylem in detail. D-G. M. esculenta cultivar. D. Vascular cambium in intense activity, formation of laticifers from these cells. E. Medullar region with cells in division. F. Region with accentuated secondary growth. G. Secondary xylem in detail. Bar $=100 \mu \mathrm{m}$. 


\section{DISCUSSION}

Diploid and tetraploid hybrids, as well as the cultivar, showed the presence of internal phloem in bicollateral bundles. In this type of organization, xylem runs parallel to both external and internal phloem. Metcalfe and Chalk (1983) reported their presence in nine genera of Euphorbiaceae, but Manihot was not one of them.

The external phloem is arranged in a continuous ring and the internal one arranged in cords next to the medullary region. Internal phloem can be found either in a continuous ring or in isolated cords (Cronquist, 1981); the latter type was observed in Manihot in the present study.

Internal phloem enhances conduction and is consequently of great advantage for desert plants, which have shorter but more intense photosynthetic periods (Fahn, 1990). However, Manihot is not a desert plant (Nassar, 2002; Nassar and Hashimoto, 2006; Ribeiro et al., 2008).

Studies on the possible physiological functions of internal phloem address a series of hypotheses; one of them proposes that internal phloem may exhibit directional and temporal differences in translocation when compared to external phloem of the same plant (Aloni and Sachs, 1973). Another explanation suggests that there are differences in the cellular composition of the internal and external phloem (Botha and Evert, 1978). Hayden and Hayden (1994) reported that internal phloem acts as a storage organ in Croton glandulosus (Euphorbiaceae). In our study, the tetraploid hybrid presents cell differentiation earlier, faster, with more quantity of cell layers, and more quantity of starch than the diploid hybrid.

These hypotheses converge towards the same point; the internal phloem of the bicollateral bundles is efficiently located to favor transport from or to the medulla because of close proximity. It is the most plausible hypothesis for internal phloem function in Manihot.

In this genus, the characterization of the vascular system with the presence of internal phloem becomes an important issue when its improvement is taken into account. Although widely distributed in South America (Nassar, 2007; Nassar et al., 2008a), few drought-resistant varieties have been cultivated. Anatomical study is a tool used by breeders for detecting drought-resistant species that can be used for selection and improvement of the crop.

\section{ACKNOWLEDGMENTS}

Research partially supported by the Brazilian National Council for Scientific Research (CNPq) and the Brazilian Coordination Office for Qualifying Graduate Personnel (CAPES). The Manihot living collection at Universidade de Brasília was established in the 1970s with the help of the International Development Research Centre (IDRC), Canada, to whom we are grateful. Thanks are due to Dr. N.M. Nayar for reviewing the manuscript.

\section{REFERENCES}

Aloni R and Sachs T (1973). The three-dimensional structure of primary phloem systems. Planta 113: 345-353.

Botha CEJ and Evert RF (1978). Observations of preferential feeding by the aphid, Rhopalosiphum maidis, on abaxial phloem of Cucurbita maxima. Protoplasma 96: 75-80.

Cronquist A (1981). An Integrated System of Classification of Flowering Plants. Columbia University Press, New York.

Dehgan B (1982). Comparative anatomy of the petiole and infrageneric relationships in Jatropha (Euphorbiaceae). Am. J. Bot. 69: 1283-1295.

Esau K (1974). O Caule: Estágio Primário de Crescimento. In: Anatomia das Plantas com Sementes (Blücher E, ed.). 
Edgard Blücher Ltda., São Paulo, 160-185.

Fahn A (1990). Plant Anatomy. 4th edn. Pergamon, New York.

Flores-Vindas E (1999). Floema. In: La Planta: Estructura y Function. Libro Universitario Regional (LUR), Cartago, 287-315. Graciano-Ribeiro D, Nassar NMA, Hashimoto DYC, Miranda SF, et al. (2008). Anatomy of polyploid cassava and its interspecific hybrids. Geneconserve 7: 620-635.

Hayden SM and Hayden WJ (1994). Stem development, medullary bundles, and wood anatomy of Croton glandulosus var. septentrionalis (Euphorbiaceae). IAWA J. 15: 51-63.

Johansen DA (1940). Plant Microtechnique. Mc-Graw Hill, New York.

Kraus JE and Arduin M (1997). Manual Básico de Métodos em Morfologia Vegetal. Seropedica, Rio de Janeiro.

Luque R, Sousa HC and Kraus JE (1996). Métodos de coloração de Roeser (1972) - modificado - e Kropp (1972) visando a substituição do azul de astra por azul de alcião 8GS ou 8 GX. Acta Bot. Bras. 10: 199-212.

Mauseth JD (1988). Plant Anatomy. Benjamin Cummings, Menlo Park.

Metcalfe CR and Chalk L (1983). Anatomy of the Dicotyledons. 2nd edn. Clarendon Press, Oxford.

Mundo SR and Duarte MR (2007). Morfoanatomia foliar e caulinar de dedaleiro: Lafoensia pacari A. St. -Hil. (Lythraceae). Lat. Am. J. Pharm. 26: 522-529.

Nassar NM (2002). Cassava, Manihot esculenta Crantz, genetic resources: origin of the crop, its evolution and relationships with wild relatives. Genet. Mol. Res. 1: 298-305.

Nassar NMA (2007). Wild cassavas, Manihot spp. Geneconserve 5: 387-414.

Nassar NMA and Hashimoto DYC (2006). Wild cassava, Manihot spp.: a survey of useful species with reference to economic value. Geneconserve 5: 284-295.

Nassar NM, Hashimoto DY and Fernandes SD (2008a). Wild Manihot species: botanical aspects, geographic distribution and economic value. Genet. Mol. Res. 7: 16-28.

Nassar NM, Graciano-Ribeiro D, Fernandes SD and Araujo PC (2008b). Anatomical alterations due to polyploidy in cassava, Manihot esculenta Crantz. Genet. Mol. Res. 7: 276-283.

Paiva JGA, Fank-de-Carvalho SM, Magalhaes MP and Graciano-Ribeiro D (2006). Verniz vitral incolor $500^{\circledR}$ : a mounting medium alternative and economically viable. Acta Bot. Bras. 20: 257-264.

Popham RA (1947). Developmental anatomy of seedling of Jatropha cordata. Ohio J. Sci. 47: 1-20.

Ribeiro D, Nassar NMA, Hashimoto D, Miranda S, et al. (2008). Anatomy of polyploid cassava and its interspecific hybrids. Geneconserve 7: 620-635.

Ye ZH (2002). Vascular tissue differentiation and pattern formation in plants. Annu. Rev. Plant Biol. 53: 183-202. 